\title{
Histological and histochemical studies of the esophagus and stomach in two types of birds with different feeding behaviors
}

\author{
Ahmed H. AbdElnaeem, Fathy M. Elshaer and Mohammed I. Rady \\ Zoology Department, Faculty of Science, Al-Azhar University, Cairo, Egypt \\ Corresponding Author: shaer82@gmail.com
}

\begin{abstract}
The present work aims to investigate the morphometrical, histological, and histochemical, aspects of the esophagus and stomach in two different Egyptian birds having different food habits. The animals under investigation are Kingfisher (Halcyon smyrnensis), and Hoopoe (Upupa epops). These birds were caught from Abou-Rawash Constituency and Nile Delta in Egypt. The birds were dissected; after which the esophagus and stomach were fixed and stained for the comparative histological study.

From the current results, it was revealed that, there are some morphometric differences between kingfisher and hoopoe in both esophagus and stomach. The esophagus wall in Kingfisher composed of only three layers or tunics: mucosa, muscularis and adventitia arranged from the inside to outside, referring to the absence of tunica submucosa;whereas, the esophagus of the Hoopoe consists of four distinct functional layers; mucosa, submucosa, muscularis and the outermost serosa. Stomach in the two studied birds is divided into two parts, glandular or true stomach (proventriculus) and the muscular stomach or gizzard (ventriculus). The glandular stomach showed moderate differences in length and width between kingfisher and hoopoe. The mucosa of proventriculus in the kingfisher consists of number of large compound folds which appear as finger-shaped structures with gastric pits; mucous cells are most conspicuously distinguished by their "empty" appearance. While, the mucosa of proventriculus in the hoopoe have both parietal cells and chief cells which occur in the middle portion of gastric glands. The gizzard wall has a thick keratinized layer called koilin, the secretion of the gizzard glands forms the koilin in hoopoe but in kingfisher the gizzard wall is small and very thin keratinoid lining.
\end{abstract}

Key words: Kingfisher, Hoopoe, carnivore, insectivore, esophagus, stomach.

\section{INTRODUCTION}

The Class Aves places second in the number of species among vertebrates. There are approximately 8,600 species of birds in the world. All birds are adapted to their different environments with respect to food sources, the seashore, ponds, small rivers, fields, or mountains. Reflecting their different life styles, birds have different feeding habits, with corresponding differences in the structures of their digestive canal ${ }^{\mathbf{( 1 )}}$. The avian alimentary canal has undergone a physiological structure in apposite to other animals to accommodate physical and chemical features of a wide variety of food types ${ }^{(2)}$, and requirements for flight ${ }^{(3)}$. Also, birds have light weight beak and gizzard instead of heavy bone, muscular and dental structure characteristic of reptiles and mammals. The morphology of an organ system varies according to the feeding habit, habitat and nature of their life-style. This phenomenon is called adaptation ${ }^{(\mathbf{4})}$.Glandular stomach (proventriculus) is lined with glandular mucous layer which secreted gastric juices such as pepsin and hydrochloric acid, by this mechanism, the ingested food with its juices passes quickly to the gizzard in which the food particles are reduced to small particles took by the intestine for more digestion and absorption ${ }^{(5)}$. Chemically, gizzard have a keratinize nature lining that termed as keratohyalin or koilin, it 


\section{Ahmed H. AbdElnaeem et al.}

was insoluble in keratinolytic solvents and resistant to pepsin ${ }^{(6)}$. The size of the gizzard changed according to the diet nature within the same species, when the bird eat dry seed in winter, the gizzard being thicker and larger in contrast when it ate fruitsduring summer ${ }^{(7) \text {. }}$

The current work is aimed to report the special anatomical, histological structures of the esophagus and stomach of the carnivore Kingfisher (Halcyon smyrnensis), and insectivore Hoopoe (Upupa epops) and correlating them with their food.

Animals:

\section{MATERIALS AND METHODS}

A total of 20 specimens, 10 samples ofwhite-throated kingfisher were collected from their natural environment of Nile delta. On the other hand, 10 samples of Hoopoe were collected from Abo Rawash area in Giza Governorate parks and Damietta Governorate in Egypt. Samples of each species were caught using amist net or picked up by some voluntaries. These animals were collected from different localities in the region of a branch of the River Nile, Egypt; during the period from September, 2015 to November, 2017.

Then samples were transported to the laboratory in Zoology Department, Faculty of Science, Al-Azhar University. Adult specimens of both bird species were sacrificed with sharp razor blade.

The studied birds were anesthetized using chloroform. The anesthetized birds were weighed; the length of the body of the two species under investigation and the length of each part of the alimentary tract were measured. The digestive tract was removed and specimens of stomach was fixed in Bouins' fluid for 18-24 h. Methods of $\mathrm{Al}-\mathrm{Attar}$ et al. ${ }^{\left({ }^{(8)}\right.}$ and Kiernan ${ }^{(\mathbf{9})}$ were employed for histological techniques. The routine stain of Harris Hematoxylin and Eosin (H\&E) were used to show the general components of the tissues and special stains of Alcian Blue (AB) and Periodic Acid Schiff reagent (PAS) were used for the general histochemical study. Sections were examined by Leica microscope, picture by digital microscopic camera.

\section{Anatomical Features:}

\section{RESULTS}

The digestive system in birds composed of buccal cavity, pharynx, esophagus, proventriculas, gizzard, small intestine, large intestine and cloaca.

The present data clarified that, the exclusively fish diet of the kingfisher (Halcyon smyrnensis) requires a relatively specialized alimentary tract for digestion. The long esophagus leads into short proventriculus. The food passes from the esophagus to a simple muscular stomach (proventriculus and ventriculus), which is highly distensible. In the proventriculus, chemical digestion commences and the food is passed as a yellowish chyme past the pyloric sphincter into the small intestine (consisting of duodenum and ileum), which leads into the large intestine. The large intestine is short and terminates in the cloaca, which opens to the out- side by the cloacal opening (Figs. 1\&2).

On the other hand, photographs of the dissection and layout of the alimentary tract within the body cavity of the Upupa epops are presented in Figures ( $3 \& 4)$. The esophagus leads into proventriculus, gizzard, pyloric sphincter into the small intestine (consisting of duodenum and ileum), which leads into the large intestine. The large intestine is long and terminates in the cloaca, which opens to the out- side by the cloacal opening. 
Histological and histochemical studies of the esophagus and stomach in two types of birds with different feeding behaviors

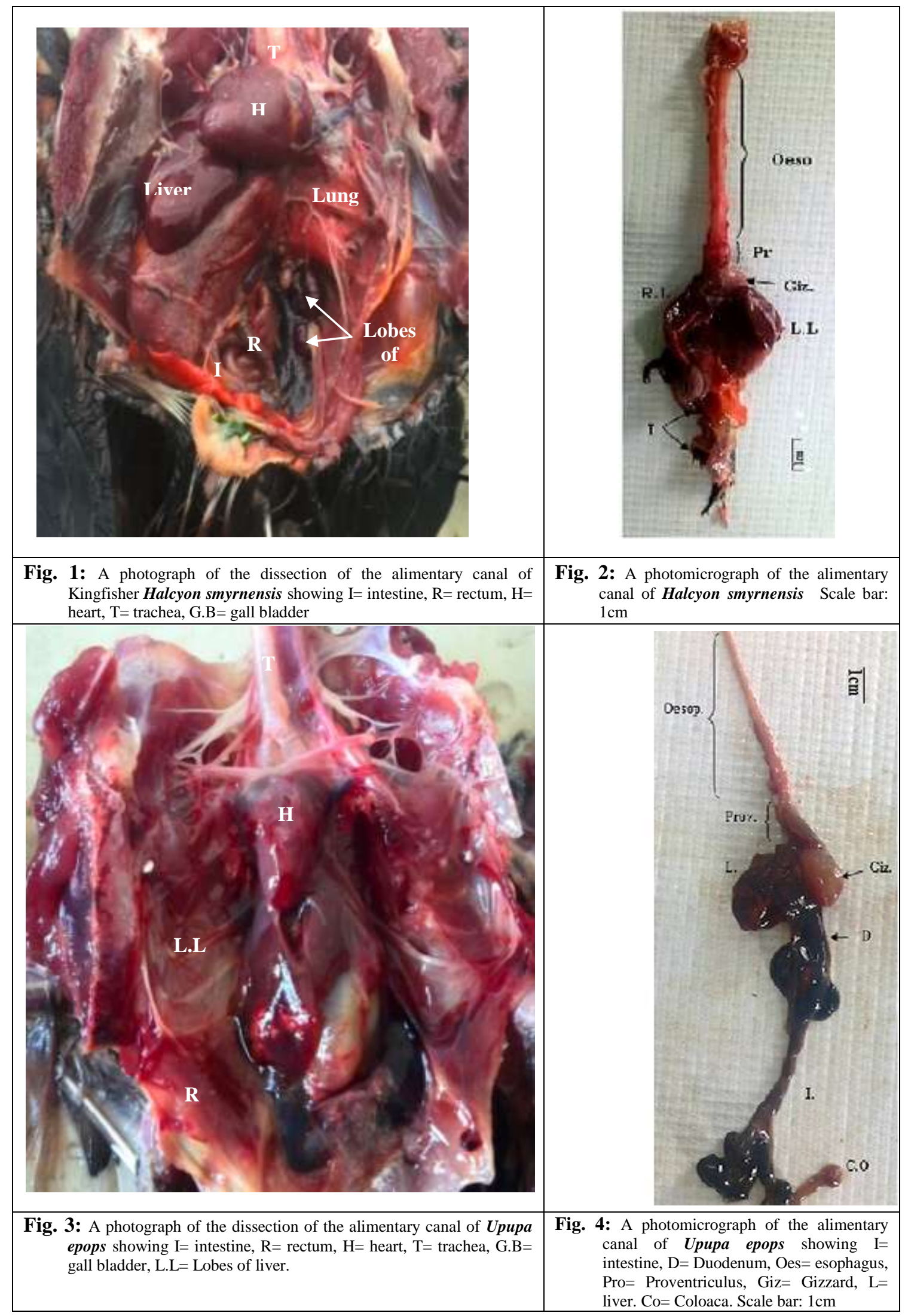




\section{Ahmed H. AbdElnaeem et al.}

\section{Histological studies}

\subsection{Esophagus:}

The histological observation in the present work showed that, the esophagealwall in Kingfisher composed of only three layers or tunics: mucosa, muscularis and adventitia arranged from the inside to outside, referring to the absence of tunica submucosa (PLATE IA). Microscopic observation of first mucosal layer of esophageal wall showed that it was consists of lamina propria, epithelia and groups of longitudinal folds without discrimination for presence of muscularis mucosae. Mucosal layer of esophageal wall lined by epithelium of non-keratinized stratified squamous epithelial tissue. Lamina propria noticed to compose of numerous mucous esophageal glands. The histological study of esophageal wall also indicated to the absence of submucosa layer because the difficulty to distinguish from the lamina propria.

The muscularis composed of smooth muscle fibers arranged in a circular layer. The fairly thick serosa or adventitia surrounds the muscularis externa. It composed of simple squamous epithelium and a capsule of connective tissue containing blood vessels, nerve fibers and fatty cells (PLATE I B).

Mucous cells are most conspicuously distinguished by their "empty" appearance (i.e., poorly stained cytoplasm) and densely-stained, basal nuclei. The nucleus in a typical mucous cell gives the impression of having been displaced and compressed by the mass of mucus accumulated in the apical end of the cell (PLATE I C \& D).

Whereas, the esophagus of the Hoopoe showing that, the esophagus consists of four distinct functional layers: mucosa, submucosa, muscularis and the outermost serosa (PLATEII A). The mucosal folds become elongated leaving only narrow lumen in the esophageal centrum, the esophagus was lined throughout its length with non-keratinized stratified squamous epithelium in addition to the goblet cells were abundant within the lamina propria mucosae. Also, a well-developed muscularis layer underlying sub-mucosa consists of one layer of circular type (PLATEII B).

The present data also observed that, in the mucosa region of the esophagus a numerous of goblet cells were abundant within the lamina propria mucosae (PLATEII C).

\subsection{Stomach:}

The histological observation in the present work observed that, the wall of the stomach in Kingfisher consists of a cranial part or glandular stomach (proventriculus) and a caudal part, the muscular stomach or gizzard (ventriculus) (PLATE III A).The glandular stomach of kingfisher showing: a narrow lumen and a spongy wall full of strongly developed glands; these glands are organized into lobules, separated by scarce dense connective tissue (lamina propria). The central part of each lobule consists of a secondary glandular excretory duct. The secondary ducts of several lobules join together to form a primary duct that opens into the lumen on a raised mucosal papilla, gastric epithelium were observed(PLATEIII $\mathrm{A} \& \mathrm{~B})$. In addition, the mucosa consists of a number of large compound folds. These folds appear as finger-shaped structures with gastric pits. Mucous cells are most conspicuously distinguished by their "empty" appearance (PLATEIII C\&D).

Whereas the histological structure of stomach in Hoopoe (U. epops) showing that, stomach consists of mucosa, muscularis mucosa, muscularis and the outermost serosa, the mucosal folds become, elongated leaving only narrow lumen in the centrum (PLATEIV A). In the (proventriculus) region the gastric glands are organized into lobules, separated by scarce dense connective tissue (lamina propria), and also both parietal cells and chief cells which occur in the middle portion of gastric glands (PLATEIV B\&C),

\subsection{Gizzard:}




\section{Histological and histochemical studies of the esophagus and stomach in two types of birds with different feeding behaviors}

The histological examination in the present work recorded that, the wall of the gizzard in Kingfisher represented by mucosa containing branched tubular glands, submucosa, muscular layer and serosa. The lining epithelium invaginates into the lamina propria to form elongated pits which each ends in several tubular gastric glands (PLATE V A). The Lumina of the tubular glands were narrow and filled with homogenous lightly stained acidophilic secretory materials, and the gastric glands were lined with short columnar or cuboidal cells with rounded vesicular basal nuclei and stained basophilic cytoplasm (PLATE V B).

On the other hand, the histological observations showed that the gizzard wall in Hoopoe has a thick keratinized layer called koilin, which formed by the secretion of the gizzard glands; a submucosa is present. The tunica muscularis consists of a thick layer of smooth muscle; there are no muscularis mucosae (PLATE V C). The gizzard glands contain two main types of cells: the most abundant are chief cells, while at the fundus of each gland only two to three basal cells with dark and rounded nucleican be found (PLATE V D\&E).

\section{Histochemical studies:}

\subsection{Esophagus:}

The Alcian blue-PAS method showed that the nature of the esophageal glands which formed of acid mucopolysaccharides. In the kingfisher, the esophageal mucosal folds have numerous esophageal glands which composed of typical mucous alveoli. These glands were loaded with positively stained material furthermore mucous glands are mostly distinguished by their dense blue color contain mass of mucous composed of acid mucosubstance accumulated in the apical end of the cell (PLATE VI A-C). While, in the esophagus of Hoopoe the goblet cells were abundant within the lamina propria mucosae and contain mucopolysaccharide content (PLATEVII A-D).

\subsection{Stomach:}

The stomach of kingfisher (proventriculus) region in the present work observed that, the mucosa consists of a number of large compound finger folds carrying mucous cells. Mucous cells are most conspicuously distinguished in the proventriculus, the cells of the surface lining epithelium of the mucosal folds shows PAS- positive mucin granules that were found to occupy the supra nuclear area of the cells (Plate VIII A-C). While the stomach of hoopoe (proventriculus) region showing: The Proventriculus wall showed neutral (red) and acid mucin (blue), Mucous cells, these glands are organized into lobules also the cells of the surface lining epithelium of the mucosal folds shows PAS-positive mucin granules that were found to occupy the supra nuclear area of the cells (Plate $\left.\mathrm{IX}_{\mathrm{A}-\mathrm{C}}\right)$.

\subsection{Gizzard:}

The superficial zone of the gizzard layer in both birds exhibited weak staining with PAS, the staining being slightly weak to moderate in Kingfisher and Hoopoe.

In the stomach (gizzard) of king fisher showing: the gizzard wall represented by mucosa containing branched tubular glands filled with homogenous lightly stained acidophilic secretory materials (Plate $\mathrm{X}_{\mathrm{A}-\mathrm{B}}$ ), the stomach (gizzard) of Hoopoe showing: the gizzard wall resemble as in kingfisher has a thick koilin layer, the secretion of the gizzard glands forms the koilin, $\left(\right.$ PLATEX $\left._{\mathrm{C}-\mathrm{D}}\right)$. 
Ahmed H. AbdEInaeem et al.

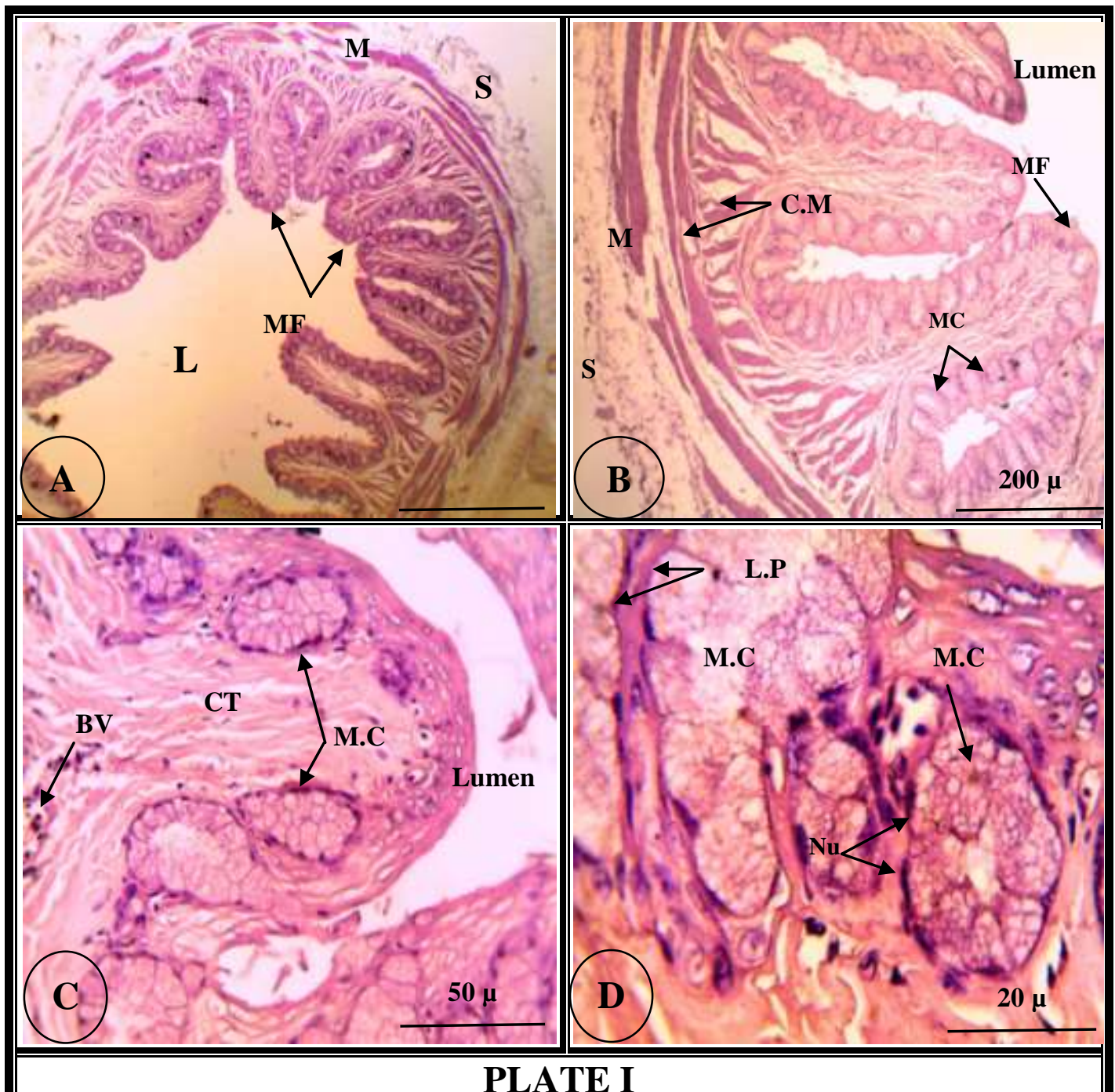

A\&B: Light micrograph of a vertical section in the esophagus region of kingfisher showing: esophageal wall formed of four layers: mucosa, muscularis and serosa. The mucosa is strongly folded, The esophageal mucosal folds (MF) have numerous mucous cells (MC), the mucosal folds become thicker, elongated and un-branched leaving only narrow lumen $(\mathbf{L})$ in the esophageal centrum. The muscularis (M) consists of circular layer of smooth muscle fibers. The fairly thick serosa $(\mathbf{S})$ or adventitia is composed of simple squamous epithelium and a capsule of connective tissue $(\mathbf{H} \& \mathbf{E}$, x500 -200 $\mu$ ).

C\&D: Enlarged vertical section in the esophagus region of kingfisher showing: mucous cells (MC) are most conspicuously distinguished by their "empty" appearance (i.e., poorly stained cytoplasm) and densely-stained, basal nuclei $(\mathrm{Nu})$. The nucleus in a typical mucous cell gives the impression of having been displaced and compressed by the mass of mucus accumulated in the apical end of the cell $(\mathbf{H} \& \mathbf{E}, \mathbf{x 5 0}-\mathbf{2 0} \boldsymbol{\mu})$. 

birds with different feeding behaviors

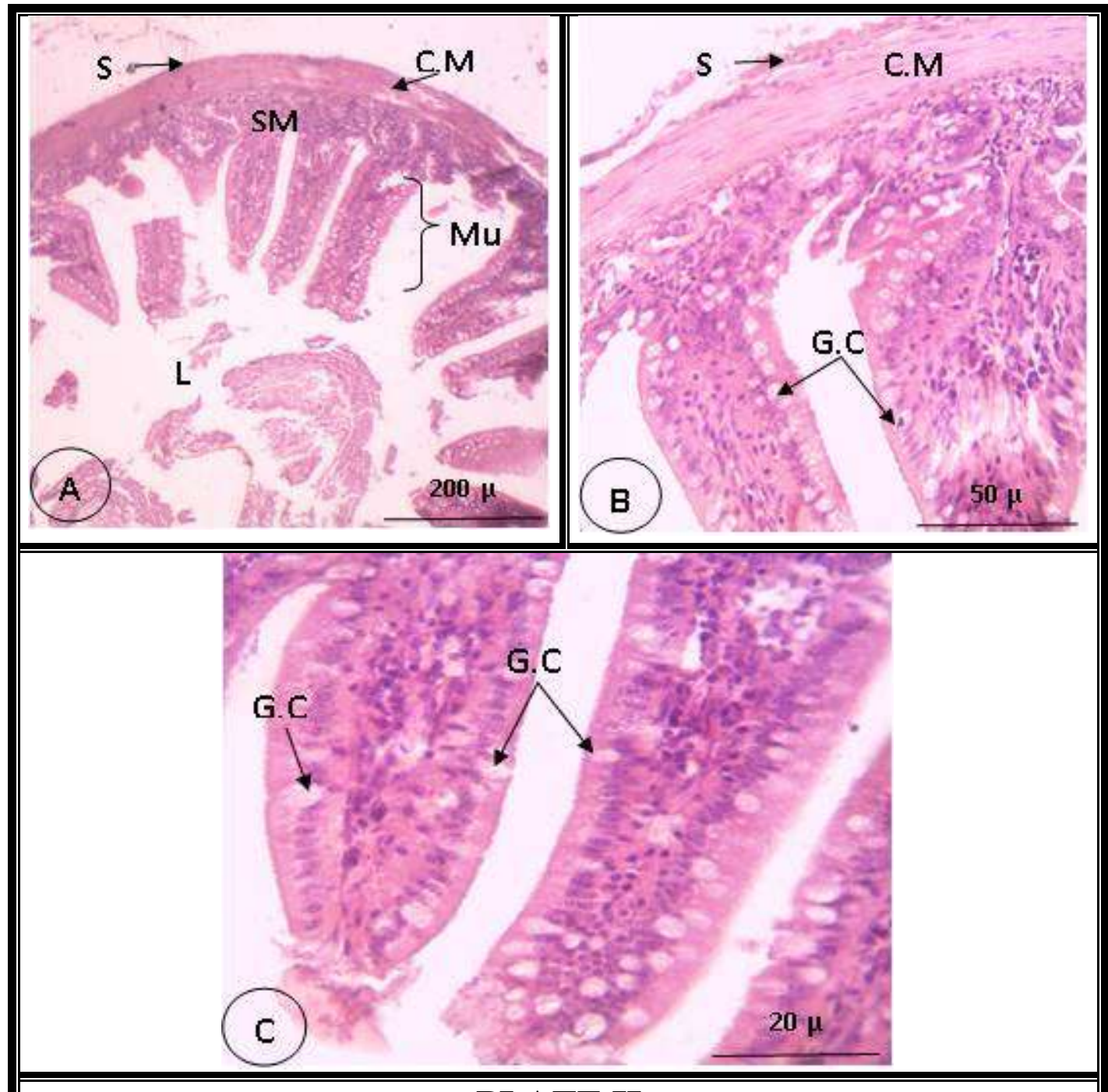

PLATE II

A: Light micrograph of a vertical section in the esophagus region of Hoopoe showing: The esophagus consists of four distinct functional layers; mucosa (Mu), submucosa (SM), muscularis (C.M) and the outermost serosa $(\mathbf{S})$,the mucosal folds become, elongated leaving only narrow lumen $(\mathbf{L})$ in the esophageal centrum $(\mathbf{H} \& \mathbf{E}, \mathbf{x} 200 \boldsymbol{\mu})$.

B: Enlarged vertical section in the esophagus region of Hoopoe showing: The esophagus was lined throughout its length with non-keratinized stratified squamous epithelium. The goblet cells (GC) were abundant within the lamina propria mucosae. A well-developed muscularis layer underlying sub-mucosa, consists of one layer of circular type $(\mathbf{C M})$ were observed $(\mathbf{H}$ $\& \mathbf{E}, \mathbf{x 5 0} \mu)$.

C: Magnified previous section in the mucosa region of Hoopoe esophagus showing: The goblet cells (GC) were abundant within the lamina propria mucosae $(\mathbf{H} \& \mathbf{E}, \mathbf{x} 20 \boldsymbol{\mu})$. 
Ahmed H. AbdEInaeem et al.

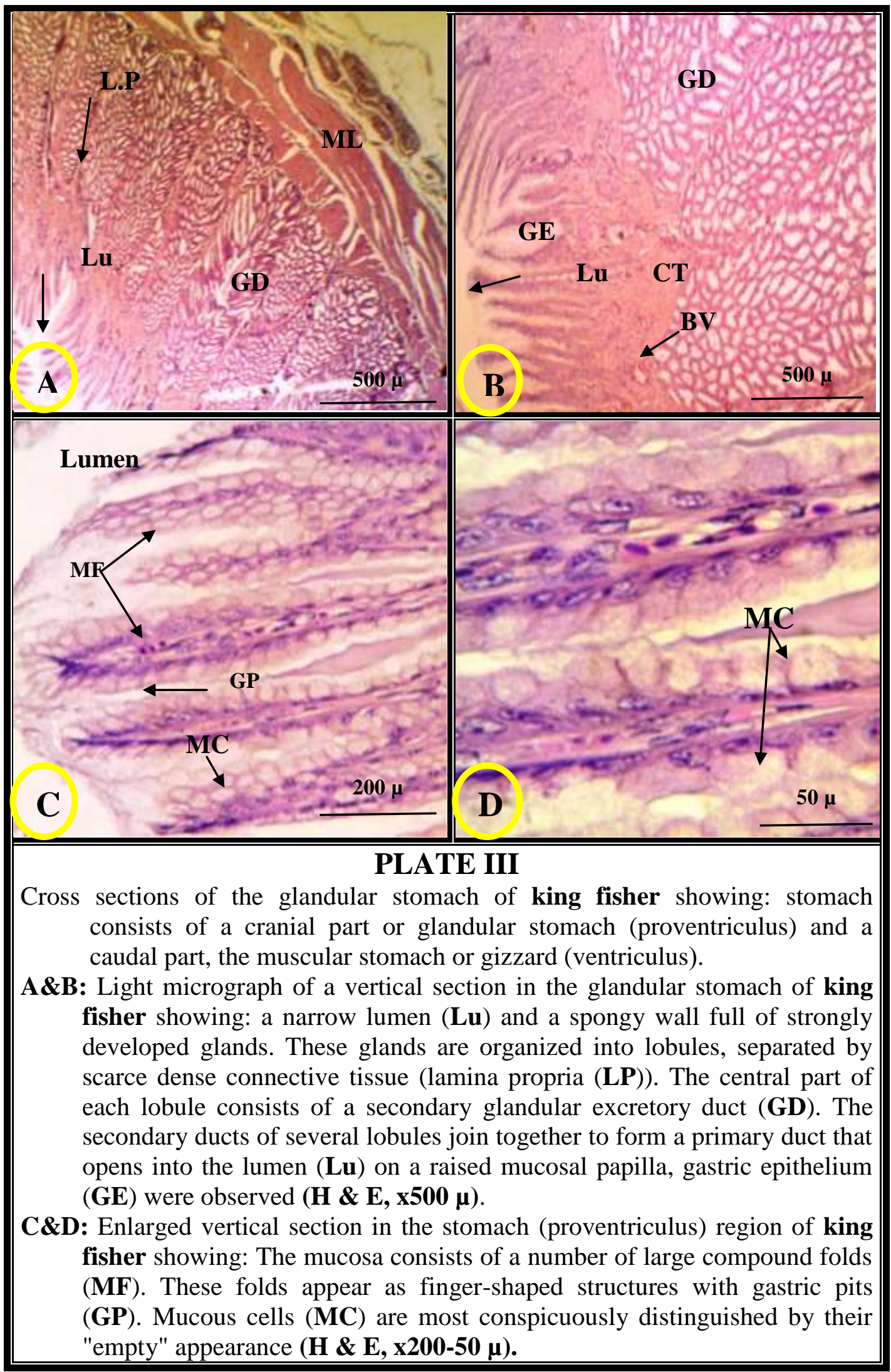


Histological and histochemical studies of the esophagus and stomach in two types of birds with different feeding behaviors 
Ahmed H. AbdEInaeem et al.

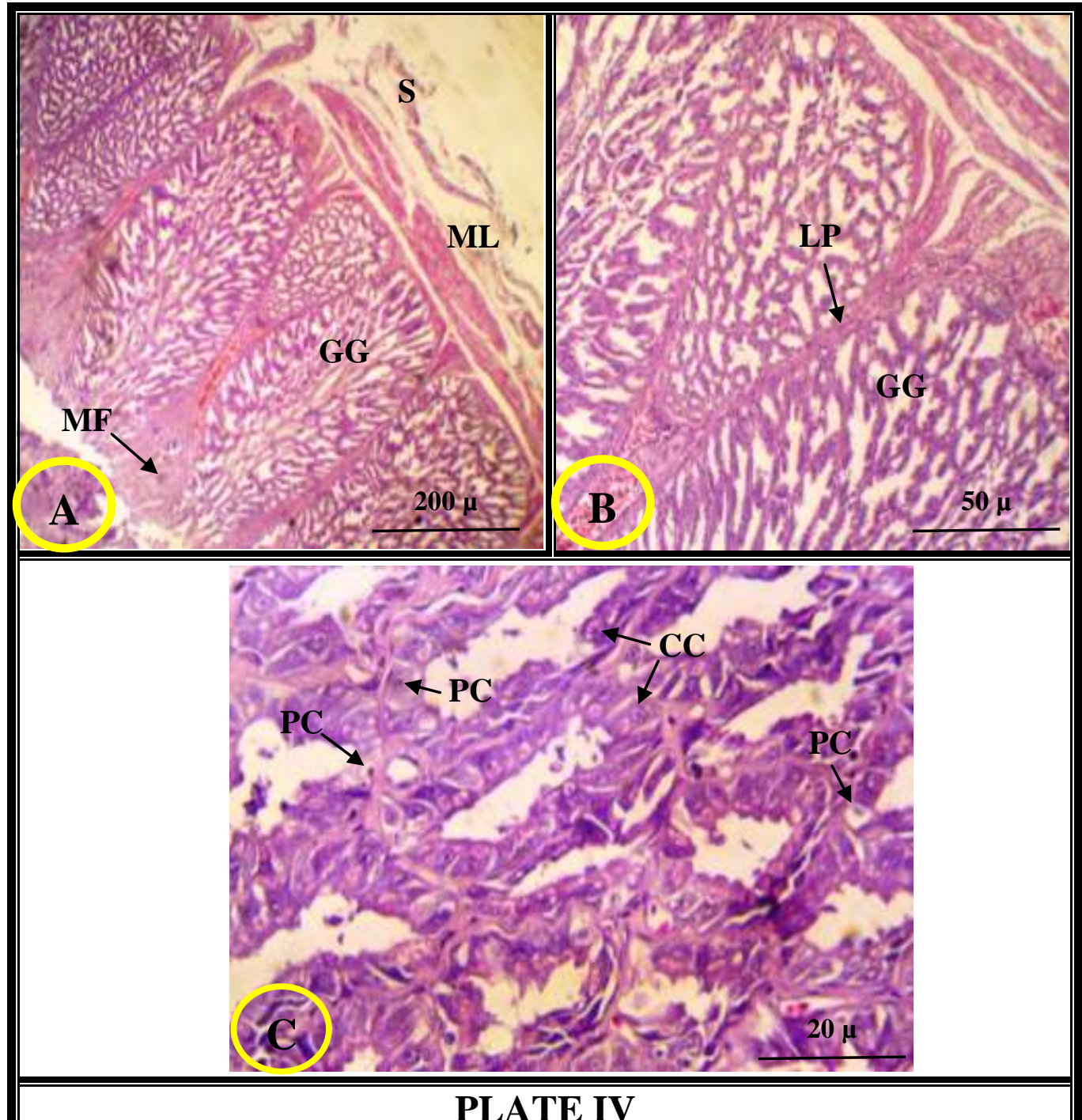

A: Light micrograph of a vertical section in the glandular stomach of Hoopoe showing: The stomach consists of mucosa, muscularis mucosa, muscularis (ML) and the outermost serosa (S); the mucosal folds (MF) become, elongated leaving only narrow lumen in the centrum $(\mathbf{H x} . \& \mathbf{E}$, $\mathbf{x} 200 \mu)$.

B: Enlarged vertical section in the stomach (proventriculus) region of Hoopoe showing: The gastric glands (GG) are organized into lobules, separated by scarce dense connective tissue (lamina propria $(\mathbf{L P})$ ). (H \& $\mathbf{E}, \mathbf{x 5 0} \boldsymbol{\mu})$.

C: Magnified previous section in the mucosa region of the stomach (proventriculus) region of Hoopoe showing: both parietal cells (PC) and chief cells $(\mathbf{C C})$ which occur in the middle portion of gastric glands $(\mathbf{H} \& \mathbf{E}, \mathbf{x} 20 \mu)$. 
Histological and histochemical studies of the esophagus and stomach in two types of birds with different feeding behaviors

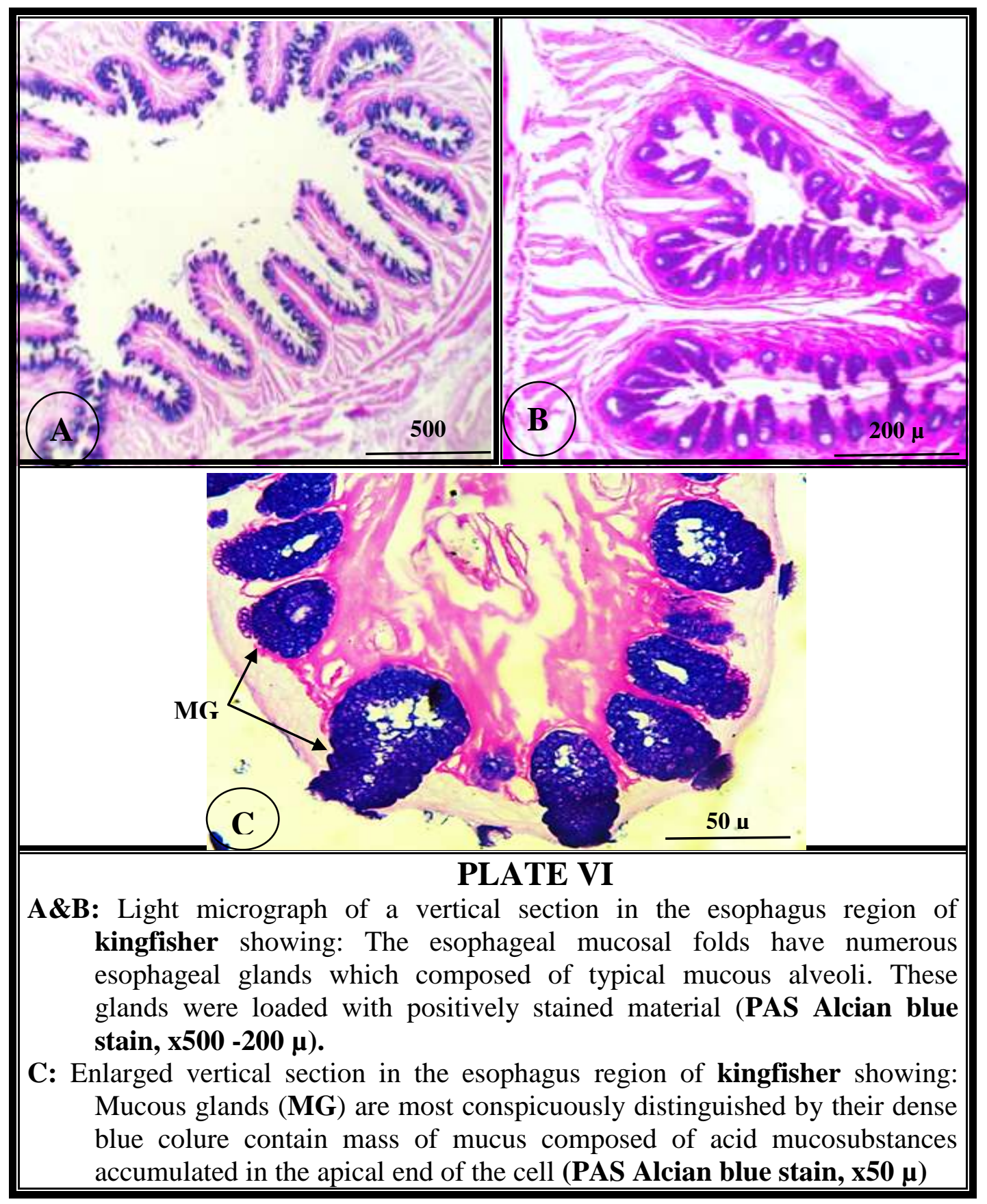


Ahmed H. AbdEInaeem et al.

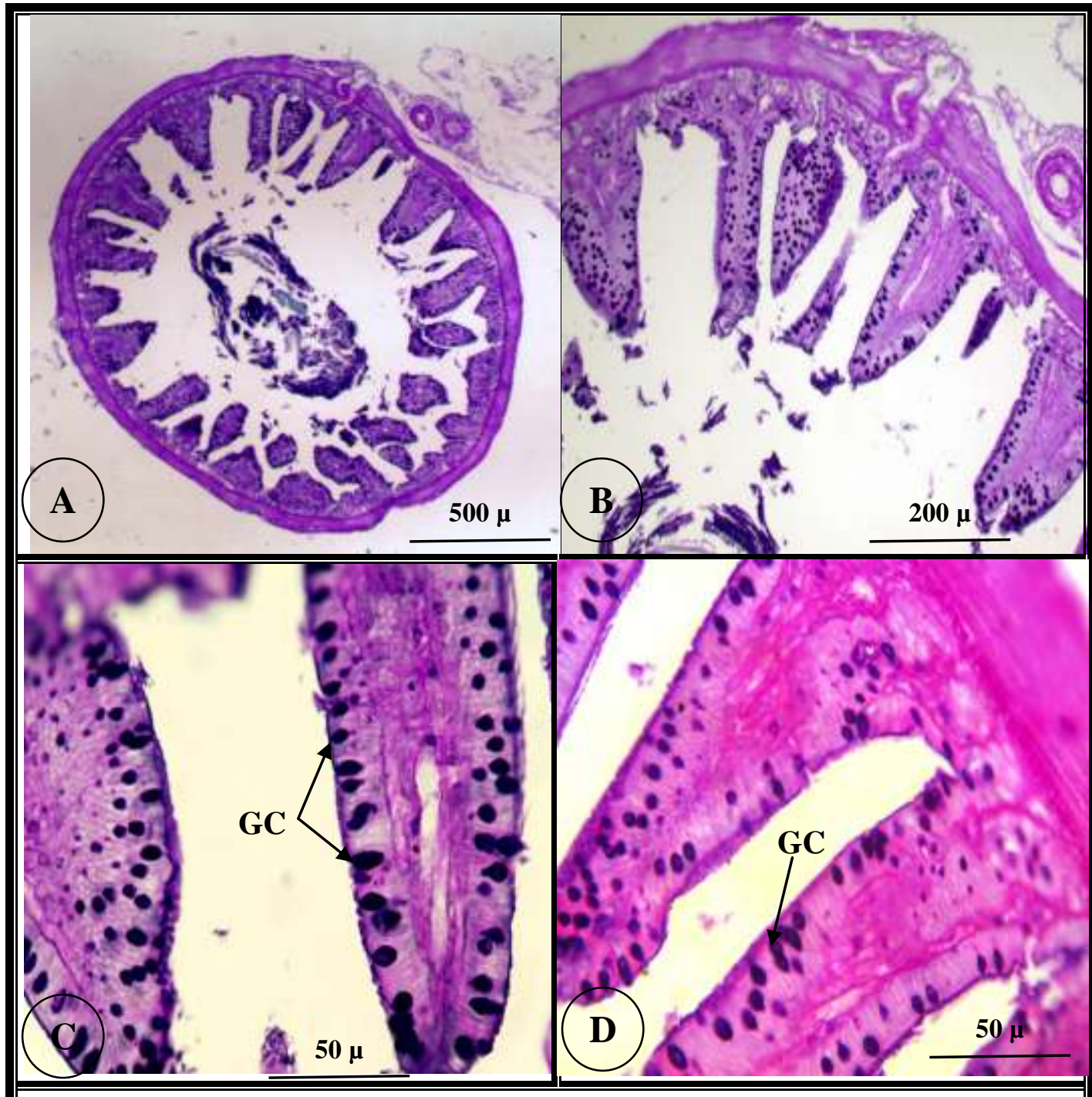

PLATE VII

A: Light micrograph of a vertical section in the esophagus region of Hoopoe showing: The esophagus consists of four distinct functional layers; mucosa, submucosa, muscularis and the outermost serosa, the mucosal folds become, elongated leaving only narrow lumen (L) in the esophageal centrum (PAS Alcian blue stain, $\mathbf{x 5 0 0} \mu$ ).

B: Enlarged vertical section in the esophagus region of Hoopoe showing: The goblet cells (GC) were abundant within the lamina propria mucosae. (Alcian PAS., $\mathbf{x 2 0 0 \mu} \mu$ ).

C\&D: Magnified previous section in the mucosa region of the esophagus of Hoopoe showing: The goblet cells (GC) were abundant within the lamina propria mucosae which contain mucopolysaccharide content. (PAS Alcian blue stain, $x 50 \mu$ ). 


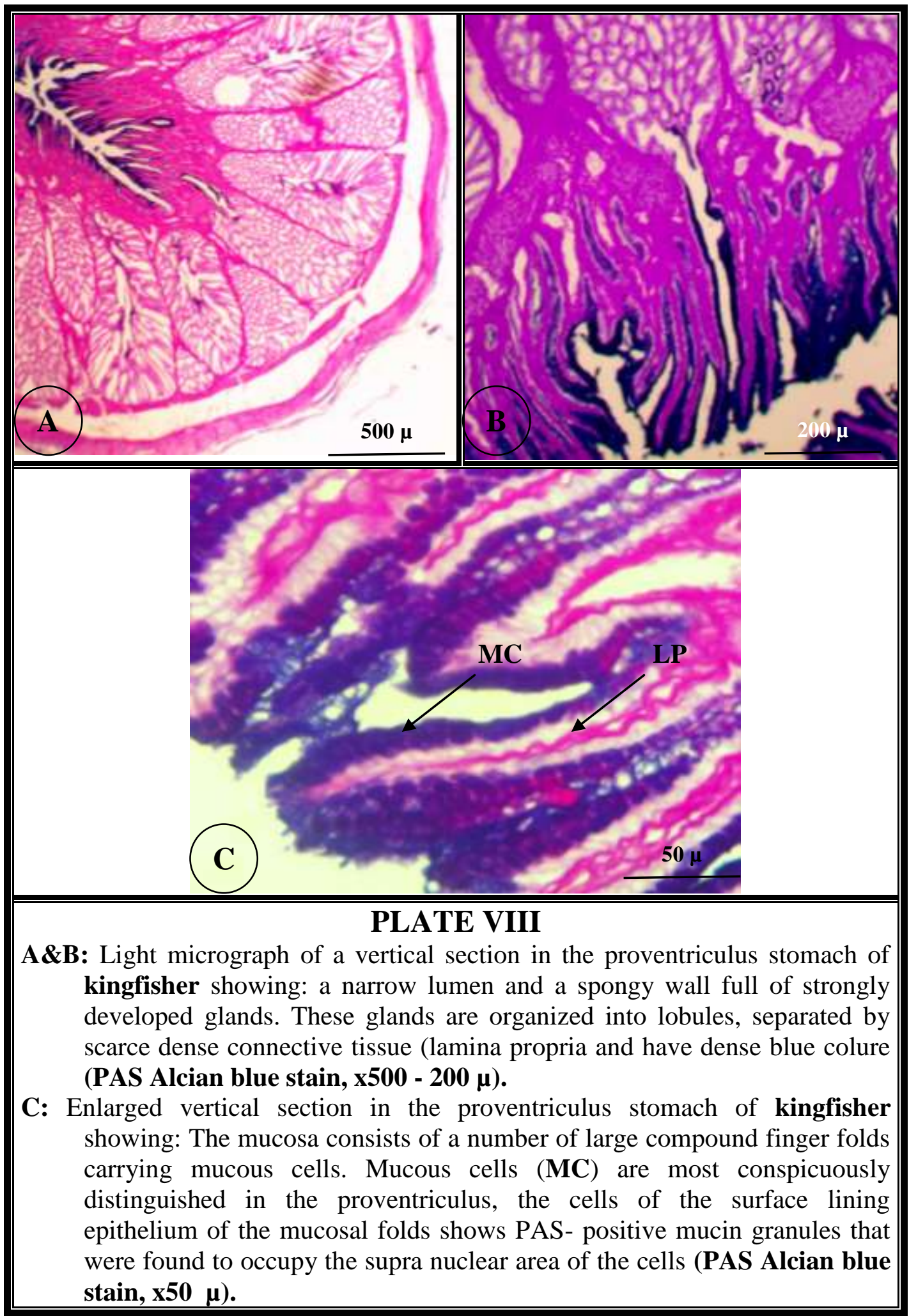




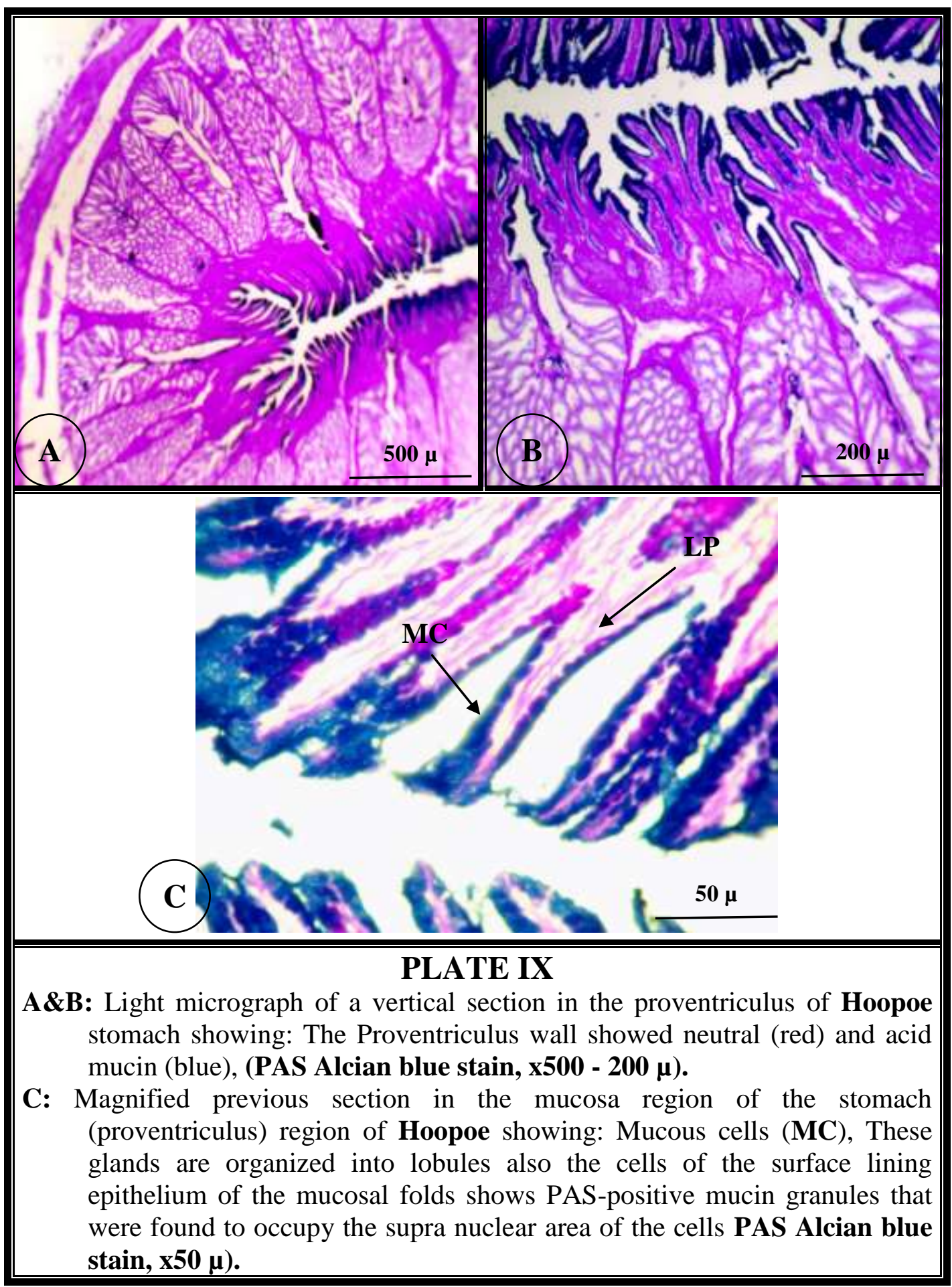




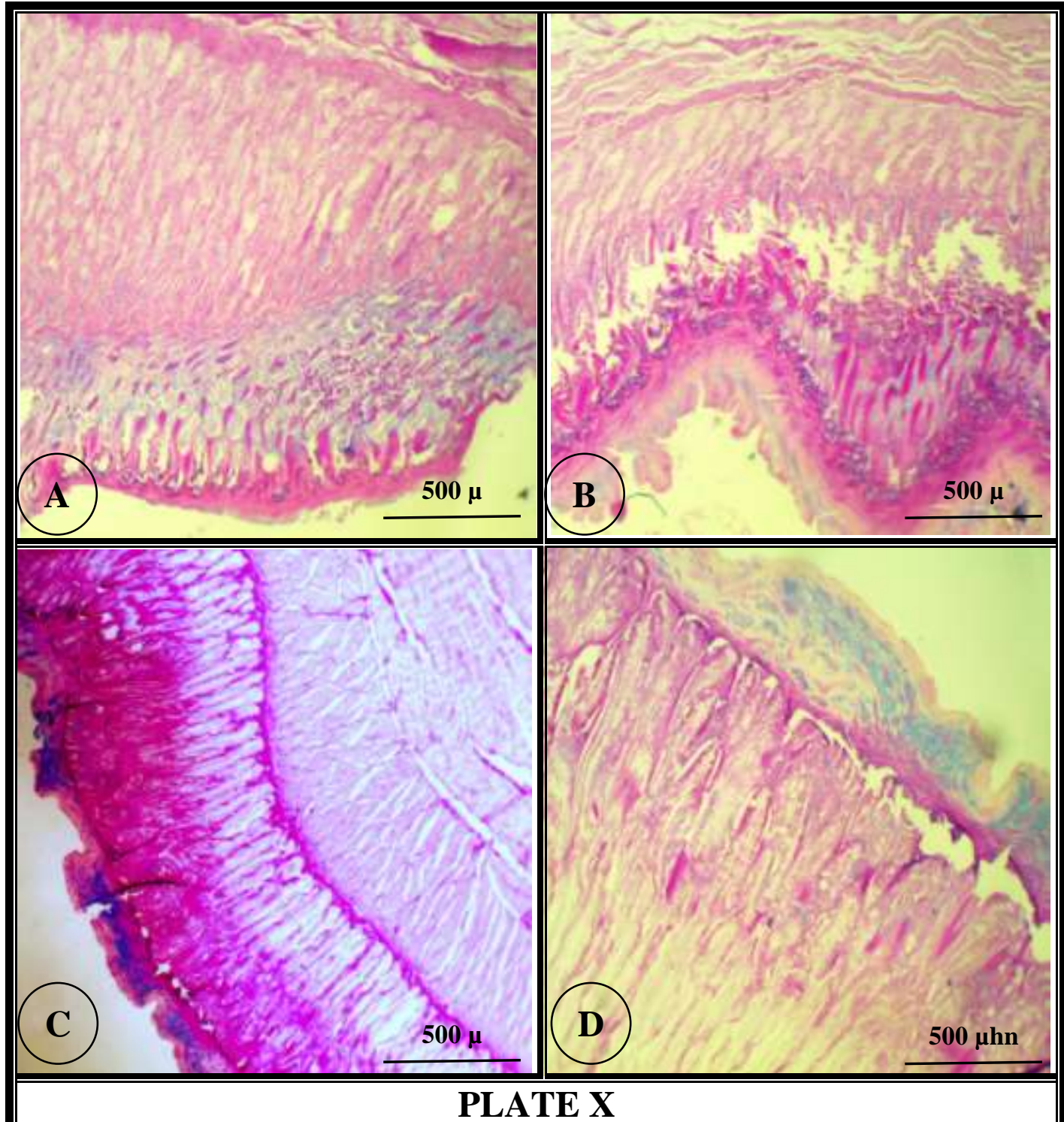

A\&B: Light micrograph of a vertical section in the gizzard stomach of kingfisher showing: the gizzard wall represented by mucosa containing branched tubular glands filled with homogenous lightly stained acidophilic secretory materials (PAS Alcian blue stain, $\mathbf{x 5 0 0 \mu} \boldsymbol{\mu})$.

C\&D: Light micrograph of a vertical section in the gizzard stomach of Hoopoe showing: the gizzard wall resemble as in kingfisher has a thick koilin layer, the secretion of the gizzard glands forms the koilin (PAS Alcian blue stain, X500 $\mu$ ). 


\section{Esophagus:}

\section{DISCUSSION}

The present data clarified that, the exclusively fish diet of the kingfishers (Halcyon smyrnensis) requires a relatively specialized alimentary tract for digestion. The long esophagus leads into short proventriculus.

The histological studies of the present investigation revealed that the esophagus is muscular tube located in right side of the neck between the orophalanx and proventiculus, and also not crop structure were observed. The esophagus of kingfishers did not need the crop to store the food because their mode of feeding, this species mainly hunts large crustaceans ${ }^{(9)}$ (Raza, 1995), insects, earthworms ${ }^{(\mathbf{1 0})}$, rodents, snakes, fish and frogs ${ }^{(\mathbf{1 1})}$. Furthermore, the young are fed mostly on invertebrates ${ }^{(\mathbf{1 2})}$. These results are agreed with many authors $\left.{ }^{(13}, \mathbf{1 4}\right)$. While the results disagree with ${ }^{(\mathbf{1 5})}$, who's found that it expended to form the crop in GreyBacked Shrike.

Histological observation shows that, the esophagus wall of kingfisher consists of three layers: mucosa, muscularis and adventitia. Submucosal layer was absent. The result was agreed with ${ }^{(\mathbf{1 3 , 1 6 , 1 7 , 1 8})}$.The esophagus of hoopoe consists of four distinct functional layers; mucosa, submucosa, muscularis and the outer most serosa. The mucosal folds become, elongated leaving only narrow lumen in the esophageal centrum and also no crop were observed in the esophagus of hoopoes species, the absent of crop may be due to the food may be stored throughout the length of the esophagus of avian species which have no $\operatorname{crop}^{(\mathbf{1 9 , 2 0})}$.

In addition, in the kingfisher the esophageal mucosal folds have numerous esophageal mucous glands which loaded with positively stained material; furthermore mucous glands are most conspicuously distinguished by their dense blue colure contain mass of mucus composed of acid mucosubstances accumulated in the apical end of the cell. While, the esophagus of Hoopoe having goblet cells were abundant within the lamina propria mucosae which contain mucopolysaccharide content. The presence of these mucous glands could be considered as another kind of esophageal adaptation with the nature of food items. These results are agreed with ${ }^{(21)}$.

\section{Stomach:}

The avian stomach consists basically of two chambers: the cranial chamber the proventriculus or glandular part, and the caudal chamber, the gizzard (ventriculus). The histological observation in the present work observed that, the wall of the stomach in a bird Kingfisher consists of a cranial part or glandular stomach (proventriculus) and a caudal part, the muscular stomach or gizzard (ventriculus). The glandular stomach of both king fisher and Upupaepops showing moderate differences in length and width, the difference between stomach of under investigation birds are probably due to the feeding habits or perhaps the amount of food engulfed by birds under investigation ${ }^{(\mathbf{2 2 , 2 3 , 2 4 )}}$. The relative size of these organs was variable according to the food habits and this may be the reasons of the differences between the two stomachs, so, in the birds that eat hard food items as in king fisherproventriculus (bird species under investigation) was wide due to the high number of glands component. These results were conformable with what have been found by ${ }^{(\mathbf{2 5})}$ developed glands organized into lobules, separated by scarce dense connective tissue (lamina propria). The central part of each lobule consists of a secondary glandular excretory duct. The secondary ducts of several lobules join together to form a primary duct that opens into the lumen on a raised mucosal papilla, gastric epithelium were observed, In addition, the mucosa consists of a number of large compound folds; which appear as finger-shaped structures with gastric pits. Mucous cells are most conspicuously distinguished by their "empty" appearance. 


\section{Histological and histochemical studies of the esophagus and stomach in two types of birds with different feeding behaviors}

Mucous cells are most conspicuously distinguished in the proventriculus of the kingfisher, the cells of the surface lining epithelium of the mucosal folds shows PASpositive mucin granules that were found to occupy the supra nuclear area of the cells While The stomach of hoopoe (proventriculus) region showing: The proventriculus wall showed neutral (red) and acid mucin (blue), Mucous cells, these glands are organized into lobules also the cells of the surface lining epithelium of the mucosal folds shows PAS-positive mucin granules that were found to occupy the supra nuclear area of the cells.

\section{Gizzard}

The superficial zone of the gizzard layer in both birds exhibited weak staining with PAS, the staining being slightly weak to moderate in Kingfisher and Hoopoe. In the stomach (gizzard) of king fisher showing: the gizzard wall represented by mucosa containing branched tubular glands filled with homogenous lightly stained acidophilic secretory materials, while the stomach (gizzard) of Hoopoe showing: the gizzard wall resemble as in kingfisher has a thick koilin layer, the secretion of the gizzard glands forms the koilin, The koilin serves as a grinding surface, enabling the ventriculus to mechanically digest food as it contracts. Insectivorous, herbivorous, and granivorous birds possess a well-developed, muscular ventriculus with a thick, abrasive koilin layer. In contrast, birds that eat foods not requiring significant mechanical digestion (i.e., carnivores and piscivores) have an almost rudimentary ventriculus and soft koilin ${ }^{(22,26)}$.

Histochemically, the present study revealed that a strong PAS-positive reaction was given by the esophageal glands. These results agree with ${ }^{(27)}$. Moreover, Leznicka ${ }^{(28)}$ reported that a meat diet had a decreasing effect on the number of these glands.

Thus, it is obvious that the anatomy as well as the histology of the alimentary canal of both birds demonstrate certain specific characteristics of functional adaptation as a reflection mode of feeding of these birds. 


\section{Ahmed H. AbdElnaeem et al.}

\section{REFERENCES}

1- Süzer, B.; Serbest, A.; Arıcan, İ.; Yonkova, P. and Yılmaz, B. (2018). A morphometric study on the skull of the turkeys (Meleagris gallopavo) Uludag Univ. J. Fac. Vet. Med. 37 (2) 93-100.

2- Klasing, K.C. (1999). Avian gastrointestinal anatomy and physiology. Semin Avian Exotic Pet Med., 8:42-50.

3- Denbow, D.M. (2000). Gastrointestinal anatomy and physiology. In: Avian Physiology, $5^{\text {th }}$ ed. (G. C.Whittow, Ed.). San Diego, California: Academic Press, 299-325.

4- Tomar, M.P.S.; Joshi, H.R.; Ramayya, P.J.; Vaish, R. andShrivastav, A.B. (2015). Avian esophagus: A comparative microscopic study Inbirds with different feeding habitats.Int. J. Med. and Health Sci., 9(8): 5-6.

5- Saleem, G. (2012). Necrotic enteritis, disease induction, predisposing factors and novel biochemical markers in broilers chickens. PhD. Thesis, Scottish Agriculture Collage, University of Glasgow.

6- Hodges, R.D. (1974). The Histology of The Fowl. Academic Press, London.

7- Gelis, S. (2013). Evaluation and treating the gastrointestinal system. Clinical Avian Medicine, 1(14):412-416.

8- Kiernan, J.A. (1999). Histological and Histochemical Methods, ( $3^{\text {rd }}$ ed.). Butterworth Heinemann, Oxford.

9- Raza, T. (1995). Crab-eating by White breasted Kingfisher Halcyon smyrnensis (Linn.). J. Bombay Natural History Soc., 92 (1): 121.

10- Yahya, H.A.S. and Shahla, Y. (1991). Earthworms in the dietary of the White breasted Kingfisher Halcyon smyrnensis (Linn.). J. Bombay Nat. Hist. Soc. 88 (3): 454.

11-Roberts, T.J. and Priddy, C. (1965). Food of the White-breasted Kingfisher Halcyon smyrnensis. J. Bombay Natural History Soc., 62 (1): 152-153.

12- Burton, N.H.K. (1998). Notes on the diet of nestling White-throated Kingfishers Halcyon smyrnensis in Malaysia. Forktail, 14: 79-80.

13-Rodrigues, M.N.; Oliveira, G.B.; Silva, R.S.S.; Tivane, C.T.; Albuquerque, J.F.G.; Miglino, M.A and Oliveira, M.F. (2012). Gross morphology and topography of the digestive apparatus in Rheas (Rhea americana americana). Pesq. Vet. Bras. 32(7):681686.

14- Bailey, T.A.; Mensah-Brown, E.P.; Samour, J.H.; Naldo, J.; Law-rence, P. and Garner, A. (1997). Comparative morphology of the alimentary tract and its glandular derivatives of captive bustards. J. Anat., 191: 387- 348.

15-Lei, Z. (2015). Histological study of the esophagus and stomach in Grey-Backed Shrike (Laniustephronotus). Int. J. Morphol,33 (2):459- 464.

16- Rossi, J.R.; Baraldi-Artoni, S.M.; Olveira, D.; Cruz, C.; Franzo, V.S. and Sagula, A. (2005). Morphology of glandular stomach (Ventriculus glandularis) and mascular stomach (Ventriculus muscularus) of the Parties rufescens. Ciecia Rural, 35:1319-1324.

17-Sagsoz, H. and Liman, N. (2009). Structure of the esophagus and morphometric, histochemical, immunohistochemical profiles of the esophageal gland during the posthatching period of Japanese quail (Coturnixcoturnix japonica). Anat. Histol. Embryo., 38(5):330- 40.

18- Al-Kinany, M.J. (2017). Histological study of esophagus in white breasted Kingfisher (Halcyon symernensis). Wasit J. Sci. \& Medicine, 10(1): 33-42.

19-Ziswiler, V. and Farner, D.S. (1972): Digestion and the digestive system. In Avian Biology, Vol. 2 (ed. Farner DS, King JR), pp. 343-430. London: Academic Press.

20- McLelland, J. (1979). Digestive system. In Form and Function in Birds (ed. King AS, McLelland J), pp. 69-181. London: Academic Press. 

birds with different feeding behaviors

21-Hamdi, H.; El-Ghareeb, A.; Zaher, M. and AbuAmod, F. (2013). Anatomical, histological and histochemical adaptations of the avian alimentary canal to their food habits: IIElanus caeruleus. Int. J. Scientific \& Engineering Res. (IJSER), 4: 1355-1364.

22- King, A.S. and Mclelland, J. (1984). Birds, Their structure and Function. $2^{\text {nd }}$ ed. Bailliere Tindall, London.

23-Kent, G.C. and Carr, R.K. (2001). Comparative anatomy of the vertebrates, (9 ${ }^{\text {th }}$ ed.) McGraw- Hill Co., New York.

24- Kardong, K.V. (1998). Vertebrates, (2 $2^{\text {nd }}$ ed.). McGraw-Hill Co., New York.

25- Abumandour, M.M.A. (2014). Histomorphological studies on the stomach of Eurasian hobby (Falconinae. Falco subbuteo, Linnaeus1758) and its relation with its feeding habits. Life Sci. J., 11(7):809-819.

26- Akester, A.R. (1986). Structure of the glandular layer and koilin membrane in the gizzard of the adult domestic fowl (Gallus gallusdomesticus). J. Anat.147, 1-25.

27-El-Banhawy, M.; Mohallal, M.E.; Rahmy, T.R. and Moawad, T.I.A. (1993). Comparative histochemical study on the proventriculus and ileum of two birds with different feeding habits. J. Egypt. Ger. Soc. Zool., 11(C):155-174.

28-Leznicka, B. (1971). The effect of diet on the histological structure of the esophagus and glandular stomach in the coot (Fulica atra). Zool. Poioniae, 3(21): 263-280. 
Ahmed H. AbdEInaeem et al.

دراسات نسيجية وكيميانسيجية للمريء والمعدة في نوعين من الطيور ذات طبيعة غذائية مختلفة

$$
\text { احمد حسن عبد النعيم- فتحى الثاعر محمد فتحى - محمد ابراهيم راضى }
$$

قسم علم الحيوان- كلية العلوم- جامعة الأزهر

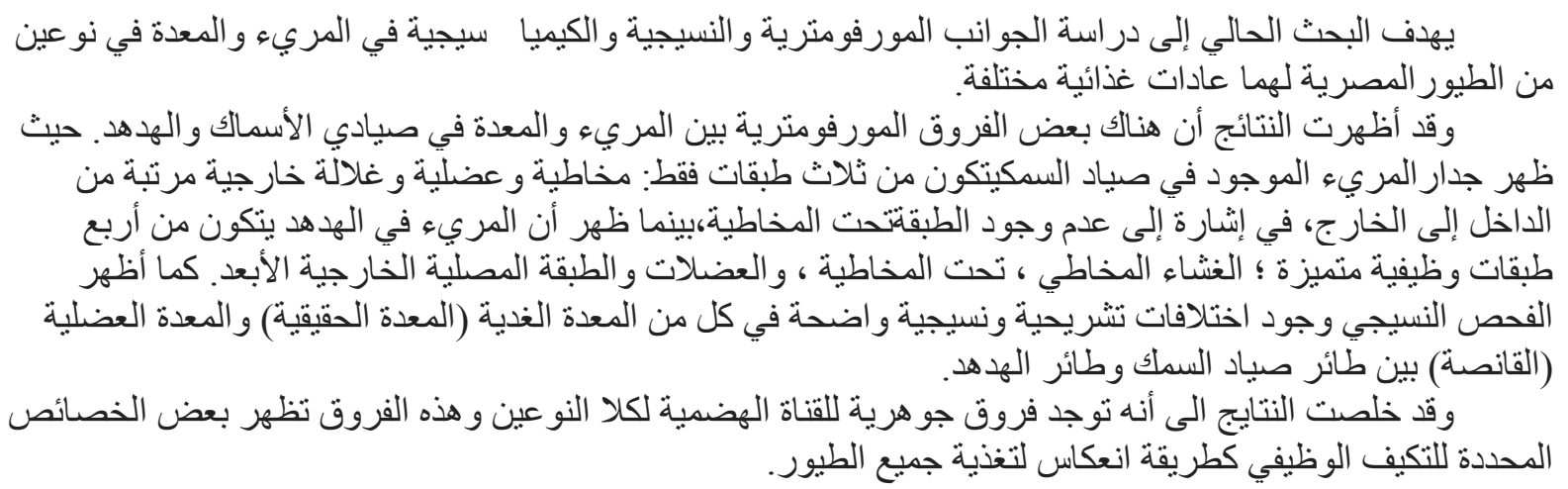

